\title{
Factors influence mental health in adolescents
}

\author{
Alva Cherry Mustamu a, I*, Nur Hafni Hasim ${ }^{2,2}$, Furaida Khasanah b,c3 \\ a Nursing Department, Poltekkes Kemenkes Sorong, Basuki Rahmad Street, Sorong, Indonesia 98416 \\ b Nursing Department, Poltekkes Kemenkes Yogyakarta, Tata Bumi Street No 3, Sleman, 55293 \\ c PUI Novakesmas, Poltekkes Kemenkes Yogyakarta, Tata Bumi Street No 3, Sleman, 55293 \\ 1 alvamustamu@gmail.com*; nurhafni705@gmail.com;ners.fura@gmail.com \\ *korespondensi penulis
}

\begin{tabular}{|c|c|}
\hline Article information: & ABSTRACT \\
\hline $\begin{array}{l}\text { Article history: } \\
\text { Accepted } \\
\text { Revised } \\
\text { Published }\end{array}$ & $\begin{array}{l}\text { The mental condition of adolescents and children in Indonesia is currently } \\
\text { alarming. Adolescents are vulnerable to various problems at the stage of } \\
\text { development such as mental and emotional problems related to emotional } \\
\text { disturbances, depression, resistance and behavioral disorders. the behavior }\end{array}$ \\
\hline $\begin{array}{l}\text { Key word: } \\
\text { Parenting style } \\
\text { Motivation } \\
\text { Mental health } \\
\text { Adolescents }\end{array}$ & $\begin{array}{l}\text { or actions that arise by each individual depends on the emotional and } \\
\text { thought conditions that arise before they decide to do something. The } \\
\text { research is a descriptive analytic study with cross-sectional design aimed } \\
\text { to determine the conditions that affect mental health in } 80 \text { teenage students } \\
\text { of SMK Negeri } 1 \text { Sorong. The measuring instrument used was a } \\
\text { questionnaire. simple logistic regression analysis test results show that } \\
\text { parenting style, motivation and discipline simultaneously have an effect on } \\
\text { adolescent mental health with a significance value }(0,000<0.005) \text {. } \\
\text { Discipline, learning motivation has an influence on adolescent mental } \\
\text { health with a significance value }(0,000<0.005) \text { but parenting does not affect } \\
\text { adolescent mental health with a significance value }(0.382>0.005) \text {. } \\
\text { Adolescents need support including the environment to prevent mental } \\
\text { disorders because it has a close relationship with academic success. }\end{array}$ \\
\hline
\end{tabular}

This is an openaccess article under the CC-BY-SA license.

\section{Introduction}

Adolescence is a unique and formative period due to various physical, emotional and social changes, including exposure to poverty, abuse, or violence, which make adolescents vulnerable to mental health problems. Begin Promoting psychological well-being and protecting adolescents from bad experiences and risk factors that can affect their potential to develop is very important for their physical and mental health well-being in adulthood.

It is estimated that $10-20 \%$ of adolescents globally experience mental health conditions, but this is still poorly diagnosed and treated 1,2. Depression and anxiety have adverse consequences on adolescent development, including achieving lower education, dropping out of school, disruption of social relations, and an increased risk of substance abuse, mental health problems and suicide ${ }^{3}$

Many factors determine mental health outcomes. The more risk factors faced by adolescents, the greater the potential impact on their mental health. Some adolescents are at 
greater risk from mental health conditions because of their living conditions, stigma, discrimination or exclusion, or lack of access to quality support and services.

The WHO Mental Health Action Plan, 2013-2020, incorporates the concepts of mental health promotion, prevention and treatment of mental illness, and rehabilitation. In particular, aspects of the development of children and adolescents, including, for example, the ability to manage thoughts, emotions, and build social relationships, and the talent for learning, are emphasized in plans as critical aspects that must be dealt with mentally.

In Indonesia, most children of this age are still undergoing education at school. There is sufficient supporting evidence about the potential of these interventions for schools to create a positive climate based on instructional and emotional support, solidarity and friendship that enhance the welfare of children and society ${ }^{4,5}$. But the problem is whether the school is able to create a positive climate so that adolescents do not experience mental problems or the school instead becomes a media of mental problems.

The literature analyzed highlights the importance of preventive interventions in which different agents work together towards a common goal of promoting the mental health of children and adolescents ${ }^{6,7}$. But to find a solution to the problem, it must be known in advance the root of the problem that has been causing interference or mental instability in them.

\section{Material and method}

This study was an observational analytic study using cross sectional study to determine the factors that influence the mental health of 80 adolescents 12-17 years old at SMK Negeri 1 Sorong taken using consecutive sampling. Materials and research tools used were 4 questionnaires namely Parental Authority Questionnaire- Revision (PAQ-R) ${ }^{8}$, disciplinary and motivational questionnaire ${ }^{9}$ and General Mental Health ${ }^{10}$. This study was approved by the ethics committee of the Sorong Health Ministry of Health Poltekkes. Analysis of research data using simple logistic regression analysis.

\section{Result and discussion}

Table 1 sociodemographic of respondents

\begin{tabular}{|c|c|c|}
\hline Variable & $\mathrm{n}$ & $\%$ \\
\hline \multicolumn{3}{|l|}{ Grade } \\
\hline Ten & 48 & 60 \\
\hline Eleven & 16 & 20 \\
\hline Twelve & 16 & 20 \\
\hline \multicolumn{3}{|l|}{ Sex } \\
\hline Male & 35 & 43,08 \\
\hline Female & 45 & 56 \\
\hline \multicolumn{3}{|l|}{ Live with parents } \\
\hline No & 4 & 5 \\
\hline Yes & 76 & 95 \\
\hline
\end{tabular}

Parental education 


\begin{tabular}{|c|c|c|}
\hline None & 2 & 2.05 \\
\hline Junior high school & 2 & 2.05 \\
\hline Senior high school & 42 & 52.05 \\
\hline University & 34 & 42.05 \\
\hline \multicolumn{3}{|l|}{ Parents profession } \\
\hline Does not work/ housewife & 2 & 2.05 \\
\hline Government employees & 32 & 40 \\
\hline Private business & 39 & 48.08 \\
\hline Farmers / workers / entrepreneurs & 7 & 8.08 \\
\hline \multicolumn{3}{|l|}{ Disciplinary score } \\
\hline Undisciplined & 11 & 13.08 \\
\hline Discipline & 69 & 86.02 \\
\hline \multicolumn{3}{|l|}{ Motivation score } \\
\hline Low & 12 & 15 \\
\hline High & 68 & 85 \\
\hline \multicolumn{3}{|l|}{ Parenting style score } \\
\hline Negative & 63 & 78.08 \\
\hline Positive & 17 & 21.02 \\
\hline \multicolumn{3}{|l|}{ Mentally healthy score } \\
\hline Mental disorders & 12 & 15 \\
\hline Mental healthy & 68 & 85 \\
\hline
\end{tabular}

Table 1 explains in detail the characteristics of the participants. Most respondents were in the tenth grade who were around 17 years old, were female, lived with parents with a high school education, worked as private employees. Parenting patterns are negative but have high motivation and discipline so that they have good mental health.

Tabel 2. Simultaneus significance test results ( $F$ test)

\begin{tabular}{lcccccc}
\hline \multicolumn{2}{l}{ Model } & Sum of Squares & df & Mean Square & F & Sig. \\
\hline & Regression & 9.418 & 4 & 3.139 & 305.175 & 0.000 \\
1 & Residual & 0.782 & 76 & 0.010 & & \\
& Total & 10.200 & 80 & & & \\
\hline
\end{tabular}

Table 2 shows that parenting, motivation and discipline simultaneously have an effect on adolescent mental health. 
Tabel 3. Significance results of partial influence

\begin{tabular}{|c|c|c|c|c|c|c|}
\hline \multirow{2}{*}{\multicolumn{2}{|c|}{ Model }} & \multicolumn{2}{|c|}{$\begin{array}{c}\text { Unstandardized } \\
\text { Coefficients }\end{array}$} & \multirow{2}{*}{$\begin{array}{c}\begin{array}{c}\text { Standardized } \\
\text { Coefficients }\end{array} \\
\text { Beta }\end{array}$} & \multirow[t]{2}{*}{$\mathbf{t}$} & \multirow[t]{2}{*}{ Sig. } \\
\hline & & B & Std. Error & & & \\
\hline \multirow{4}{*}{1} & (Constant) & -0.038 & 0.032 & & -1.207 & 0.231 \\
\hline & Disciplinary & 0.820 & 0.050 & 0.791 & 16.517 & 0.000 \\
\hline & Motivation & 0.215 & 0.049 & 0.215 & 4.405 & 0.000 \\
\hline & $\begin{array}{l}\text { Parenting } \\
\text { style }\end{array}$ & -0.007 & 0.028 & -0.008 & -0.248 & 0.805 \\
\hline
\end{tabular}

Table 3 shows that discipline and motivation have a linear relationship to mental health. But parenting does not have a linear relationship to adolescent mental health.

As the economy and the rate of urbanization grew rapidly in Sorong, more and more rural labor surpluses left the countryside and flocked to big cities, and the floating population had skyrocketed. In recent years, family migration has become the main mode of migration of the Sorong floating population, which means more and more parents are taking their children out of their permanent registered residences to new cities where they work and live. The number of teenagers in migrant families has increased dramatically over the past few years.

During this immigration process, children and adolescents in migrant families often have to face great pressure to adapt to life in the city, which causes various mental health problems. Evidence shows that the incidence rate of children's mental health problems in migrant families is higher than in non-migrant families. ${ }^{11}$ Parenting style is an important factor in family education and is a relatively stable pattern of behavior and tendencies in raising and educating children through daily activities. The parenting style generally falls along a continuum between two weak and overly punitive anchors, with extremes in both directions defined as negative. Positive parenting is a strategy that involves warmth, sensitivity, acceptance, and responsiveness to children ${ }^{12}$. Previous studies have shown that parenting style and ideas are important influencing factors for children's psychological development and behavior. ${ }^{13}$

Parenting style and ideas are important influencing factors for the psychological development and behavior of children. In studies of childcare styles in the families of shunt migrants and eastern Indonesia, parents tend to usually adopt some negative parenting styles (for example, punishment and authoritarianism) and rarely adopt positive parenting styles (for example, emotional warmth and understanding). LLorca et $\mathrm{al}^{14}$ dan Verhoeven et al. ${ }^{15}$ reported that poor parenting style would increase the incidence rate of children's psychological problems, and negative parenting styles, such as excessive protection and 
excessive interference, were more likely to increase a child's social anxiety. A parenting style that is refusing, overprotective, and anxious is related to increasing children's anxiety. A study from China also found that parental orders and reprimands negatively correlated with adolescent self-esteem and emotional balance, and positively related to social anxiety and behavior problems. ${ }^{16}$ In addition, mothers of daughters with high social anxiety tend to control and assist their daughters in their daily lives and learning. Furthermore, fathers of children with high anxiety show more controlling behavior ${ }^{17}$. Most of this research, however, mainly focuses on childcare style and social anxiety in non-migrant families, while several studies examine the relationship between parenting style and social anxiety of adolescents in migrant families.

Parental warmth and effective parenting behaviors (such as the use of appropriate boundaries and disciplines) distinguish tough children from those who have more social and emotional problems among school-age children who are exposed to physical violence and the threat of violence against their mother. In addition, the lack of warmth and support that characterizes authoritarian parenting styles undermines parent-child relationships and causes children to rebel against their parents' demands, potentially in the form of externalizing problems, or to display overly submissive behavior, which can manifest themselves in internalizing problem. Indeed, empirical studies have shown that authoritarian parenting is associated with externalization as well as internalization problems in children, with respect to permissive styles, research has shown that permissive mothering significantly predicts the development of externalizing behavior in toddlers. ${ }^{18}$ Furthermore, parental refusal to teach children that positive outcomes (eg warmth and parental consent) are rare and do not depend on one's actions, and this uncertainty can prevent attempts at children's independence. ${ }^{19}$.

In this study we found that respecting and respecting and increasing motivation, and the perspective of adolescents would be very suitable for use during transitions such as youth and young adults, where autonomy is an important developmental task. In a long-term view, stabilizing mental conditions in adolescents can lead to better control of chronic conditions and the prevention of life-long mental health consequences.

Reinauer et $\mathrm{al}^{20}$ found that motivation can reduce comorbidity, increase long-term adherence to therapy and can change maladaptive health dysfunctional behavior, which can become chronic in adolescence and early adulthood. methods for overcoming individual and structural barriers to the use of mental health services, which must be identified and reduced in the long run

Our results are consistent with previous studies which also confirm that there is a significant relationship between achievement motivation and psychological well-being ${ }^{212223}$. Achievement motivation can be considered as the main introduction to success in adolescents in the future. In general, those who are motivated to be successful are more interested in moving towards the future and pay attention to innovation activities from an early age.

Teenagers in Indonesia generally spend more than 6 hours a day and an average of nearly 1,200 hours each year in school. Therefore, it is not surprising that schools have a large influence on adolescent mental health and may even be more influential than the home 
environment. Therefore, school policies can be encouraged to improve mental health of adolescents.

In overcoming this need, Lau et al. ${ }^{24}$ promoting student style of students to identify aspects of school discipline that might be able to estimate the mental health risks of adolescents. The four sections that are the focus of research are drug use, violent aggression, intimidation involvement, and depressive symptoms. The result found is that the style of educating teenagers in schools that are authoritative has the lowest risk, while adolescents in schools that are too loose have the highest risk.

The results of this study are in line with the results of this study which found that the majority of respondents experienced negative parenting that is authoritarian from their parents but did not have a linear relationship with their mental health. This means that the authoritarian parenting that is the culture of eastern societies in Indonesia has a positive impact because it does not reduce the motivation and discipline of adolescents. Most important is mental health is a very important impact on adolescent development because it can affect their discipline and motivation even if the teenager must be educated in an authoritarian way or not.

The era of technology supports teenagers to create their own world and environment because they can access the best information including parenting. In addition, the era of technology can open up parents' insight to educate children and children can freely invite parents to discuss.

The results of this study require further study considering the place of this research was conducted in eastern Indonesian people who have harsh behavior and the distribution of education and technology are less evenly distributed compared to central and western Indonesia. In addition, research with a larger sample is needed to understand the appropriateness of school discipline styles with parental discipline styles. Similar findings for school discipline styles have implications for how school professionals conceptualize their role in facilitating a warm and structured environment.

The current study raises new questions about how to produce broad policy changes that are in line with the conceptualization of the principles of discipline, parenting parents and the promotion of effective motivation specifically for adolescents. And how to facilitate the implementation of school discipline policies and authoritative parenting parents.

\section{Conclusion}

The results of this study found that simultaneously, parenting, discipline and motivation have a linear relationship with adolescent mental health. But separately, only discipline and motivation have a close relationship with health. Parenting patterns do not have a linear relationship with adolescent mental health.

\section{Reference}

1. WHO. Adolescent mental health. https://www.who.int/news-room/factsheets/detail/adolescent-mental-health. Published 2019. Accessed February 6, 2020. 
2. Vereinte Nationen, Büro für Drogenkontrolle und Verbrechensbekämpfung. World Drug Report 2019.; 2019.

3. Hetrick SE, Cox GR, Witt KG, Bir JJ, Merry SN. Cognitive behavioural therapy (CBT), third-wave CBT and interpersonal therapy (IPT) based interventions for preventing depression in children and adolescents. Cochrane Database of Systematic Reviews. 2016;(8). doi:10.1002/14651858.CD003380.pub4

4. Bloemraad I, Terriquez V. Cultures of engagement: The organizational foundations of advancing health in immigrant and low-income communities of color. Soc Sci Med. 2016;165:214-222. doi:10.1016/j.socscimed.2016.02.003

5. Puffer ES, Green EP, Sikkema KJ, Broverman SA, Ogwang-Odhiambo RA, Pian J. A church-based intervention for families to promote mental health and prevent HIV among adolescents in rural Kenya: Results of a randomized trial. J Consult Clin Psychol. 2016;84(6):511525. doi:10.1037/ccp0000076

6. Atkins MS, Shernoff ES, Frazier SL, et al. Redesigning community mental health services for urban children: Supporting schooling to promote mental health. J Consult Clin Psychol. 2015;83(5):839-852. doi:10.1037/a0039661

7. Kia-Keating M, Santacrose DE, Liu SR, Adams J. Using Community-Based Participatory Research and Human-Centered Design to Address Violence-Related Health Disparities Among Latino/a Youth. Fam Community Health. 2017;40(2):160-169. doi:10.1097/FCH.0000000000000145

8. Reitman D, Rhode PC, Hupp SDA, Altobello C. Development and Validation of the Parental Authority Questionnaire - Revised. Journal of Psychopathology and Behavioral Assessment. 2002;24(2):119-127. doi:10.1023/A:1015344909518

9. SURANTO. Hubungan antara kesehatan mental dan motivasi belajar dengan kedisiplinan siswa kelas xi sma negeri di Kecamatan purbalingga kabupaten purbalingga Tahun pelajaran 2008/2009. 2009. https://eprints.uns.ac.id/8173/. Accessed February 8, 2020.

10. Dwairy M, Menshar KE. Parenting style, individuation, and mental health of Egyptian adolescents. J Adolesc. 2006;29(1):103-117. doi:10.1016/j.adolescence.2005.03.002

11. Xu F, Xing H, Yu W, Chen S, Li H. Health-related quality of life and influencing factors among migrant children in Shaoxing, China. Health and Quality of Life Outcomes. 2017;15(1):100. doi:10.1186/s12955-017-0679-8

12. Kawabata Y, Alink LRA, Tseng W-L, van IJzendoorn MH, Crick NR. Maternal and paternal parenting styles associated with relational aggression in children and adolescents: A conceptual analysis and meta-analytic review. Developmental Review. 2011;31(4):240-278. doi:10.1016/j.dr.2011.08.001

13. Csomortáni DZ. [Prospective study of children's perceptions of parental behavior: psychometric properties of the Hungarian version of the EMBU-C questionnaire]. Psychiatr Hung. 2013;28(4):399-413.

14. Llorca A, Cristina Richaud M, Malonda E. Parenting, Peer Relationships, Academic Self-efficacy, and Academic Achievement: Direct and Mediating Effects. Front Psychol. 2017;8. doi:10.3389/fpsyg.2017.02120

15. Verhoeven M, Bögels SM, van der Bruggen CC. Unique Roles of Mothering and Fathering in Child Anxiety; Moderation by Child's Age and Gender. J Child Fam Stud. 2012;21(2):331-343. doi:10.1007/s10826-011-9483-y

16. Liu L, Wang N, Tian L. The Parent-Adolescent Relationship and Risk-Taking Behaviors Among Chinese Adolescents: The Moderating Role of Self-Control. Front Psychol. 2019;10. doi:10.3389/fpsyg.2019.00542 
17. Greco LA, Morris TL. Paternal Child-Rearing Style and Child Social Anxiety: Investigation of Child Perceptions and Actual Father Behavior. Journal of Psychopathology and Behavioral Assessment. 2002;24(4):259-267. doi:10.1023/A:1020779000183

18. Rinaldi CM, Howe N. Mothers' and fathers' parenting styles and associations with toddlers' externalizing, internalizing, and adaptive behaviors. Early Childhood Research Quarterly. 2012;27(2):266-273. doi:10.1016/j.ecresq.2011.08.001

19. Varela RE, Niditch LA, Hensley-Maloney L, Moore KW, Creveling CC. Parenting practices, interpretive biases, and anxiety in Latino children. J Anxiety Disord. 2013;27(2):171177. doi:10.1016/j.janxdis.2012.12.004

20. Reinauer C, Viermann R, Förtsch K, et al. Motivational Interviewing as a tool to enhance access to mental health treatment in adolescents with chronic medical conditions and need for psychological support (COACH-MI): study protocol for a clusterrandomised controlled trial. Trials. 2018;19(1):629. doi:10.1186/s13063-018-2997-5

21. Nisa SU, Qasim N. Relationship of achievement motivation and psychological wellbeing in adolescents. :3.

22. Nwankwo C, Okeke CP, Okeke OJ. Impact of Motivation on the Psychological Wellbeing of Nurses in Enugu Metropolis. International Journal of Academic Research in PSYCHOLOGY. 2018;5(1):14.

23. Li Y, Lan J, Ju C. Self-esteem, gender, and the relationship between extraversion and subjective well-being. Social Behavior and Personality. 2015;43(8):1243-1254. doi:10.2224/sbp.2015.43.8.1243-1254

24. Lau C, Wong M, Dudovitz R. School Disciplinary Style and Adolescent Health. Journal of Adolescent Health. 2018;62(2):136-142. doi:10.1016/j.jadohealth.2017.08.011 